\title{
PENGgunaAN SAKSI MaHKOTA DALAM PEMBUKTIAN TINDAK PIDANA PERJUdian DI PENGADILAN NEGERI BANGKALAN
}

\author{
Lailatul Khoiriyah $\mid$ Jl. Pondok Raudhatul Musthofa Tambak \\ analayla.al@gmail.com $\quad$ Lekok Lekok Pasuruan
}

\begin{abstract}
This paper provides an overview of prosedural law of Islam against the use of crown witness in the process of proving the crime of gambling No. 216/Pid.B/PN.Bkl. The existence of crown witness in proving the decision No. 216/Pid.B/2012/PN.Bkl is allowed according to prosedural law of Islam by the reason no other supporting evidences for deciding the case in the trial. The crown witness, in this case, is indispensable because it is a key witness. On this circumstance, crown witness is regarded as darûrât (the difficult condition) because it can only be issued by an investigator as long as no other witnesses that can open a secret crime and conducted under oath. As a consequence of the crown witness itself is dispensed in the form of prosecution of his case or given a demand which is very light when the case is transferred to the court or be forgiven for the mistake that has been done.
\end{abstract}

Keywords: Prosedural law of Islam, crown witness, evidence.

Abstrak: Tulisan ini membahas tentang tinjauan fiqh murâfa'ât terhadap penggunaan saksi mahkota dalam proses pembuktian tindak pidana perjudian No.216/Pid.B/PN.Bkl. Keberadaan saksi mahkota dalam pembuktian putusan Nomor 216/Pid.B/2012/PN.Bkl itu diperbolehkan menurut fiqh murâfa'ât karena alasan tidak ada bukti lain yang mendukung untuk memutus perkara dalam persidangan, dan saksi mahkota ini sangat diperlukan karena merupakan saksi kunci. Saksi mahkota dihukumi ḍarûrât karena alasan saksi mahkota bisa dikeluarkan oleh penyidik dengan syarat tidak ada saksi lain selain saksi mahkota yang dapat membuka takbir kejahatan terdakwa, dan dilakukan di bawah sumpah. Adapun konsekuensi dari saksi mahkota itu sendiri ialah dalam bentuk ditiadakan penuntutan terhadap perkaranya atau diberikannya suatu tuntutan yang sangat ringan apabila perkaranya dilimpahkan ke pengadilan atau dimaafkan atas kesalahan yang pernah dilakukan.

Kata Kunci: Fiqh murâfa'ât, saksi mahkota, pembuktian 


\section{Pendahuluan}

Pembuktian merupakan masalah yang memegang peranan penting dalam proses pemeriksaan sidang pengadilan. Melalui proses pembuktian dapat ditentukan nasib terdakwa apakah kesalahan terdakwa patut dihukum atau sebaliknya.

Dalam kedudukannya sebagai instrumen hukum publik yang mendukung pelaksanaan dan penerapan ketentuan hukum pidana materiil, maka Undang-Undang Nomor 8 Tahun 1981 tentang Kitab Undang-Undang Hukum Acara Pidana (KUHAP) telah memiliki rumusan sistem pembuktian tersendiri, ${ }^{1}$ yaitu terdapat dalam Pasal 183 sampai dengan Pasal 202 KUHAP.

Adapun rumusan sistem pembuktian tersebut adalah untuk mendukung tujuan dari pada hukum acara pidana, yaitu untuk mencari dan memperoleh atau setidak-tidaknya mendekati kebenaran materiil. Kebenaran materiil adalah kebenaran yang selengkap-lengkapnya dari suatu perkara pidana dengan menerapkan ketentuan hukum acara pidana secara jujur dan tepat, dengan tujuan untuk mencari pelaku yang dapat didakwakan melakukan pelanggaran hukum, meminta pemeriksaan dan putusan dari pengadilan guna menemukan apakah terbukti bahwa suatu tindak pidana telah dilakukan, dan apakah orang yang didakwakan ini dapat dipersalahkan. ${ }^{2}$

Implementasi rumusan sistem pembuktian tersebut harus berpedoman pada asas-asas yang berlaku dalam proses peradilan pidana, seperti asas praduga tidak bersalah (presumption of innocence), dan asas persamaan di hadapan hukum (equality before the law). ${ }^{3}$ Sebagai perwujudan asas praduga tidak bersalah, maka di dalam Pasal 66 KUHAP ditegaskan "bahwa tersangka atau terdakwa tidak dibebani kewajiban pembuktian". ${ }^{4}$

Sebagai subjek dalam pemeriksaan, maka tersangka atau terdakwa diberikan kebebasan untuk melakukan pembelaan diri terhadap dakwaan yang ditujukan kepada dirinya. Pasal 52 KUHAP menyebutkan bahwa "dalam pemeriksaan pada tingkat penyidikan dan pengadilan, tersangka atau terdakwa berhak memberikan keterangan secara bebas kepada

\footnotetext{
${ }^{1}$ Kansil, Pengantar Ilmu Hukum dan Tata Hukum Indonesia (Jakarta: Balai Pustaka, 1989), 349.

${ }^{2}$ Andi Hamzah, Hukum Acara Pidana Indonesia (Jakarta: Sinar Grafika, 2008), 8.

${ }^{3}$ Ibid., 22.

${ }^{4}$ KUHAP (Kitab Undang-Undang Hukum Acara Pidana).
} 
penyidik atau hakim". 5 Dengan kata lain, terdakwa mempunyai hak untuk mengingkari terhadap dakwaan yang didakwakan kepadanya karena dilindungi oleh asas praduga tidak bersalah.

Berdasarkan teori pembuktian dalam hukum acara pidana, keterangan yang diberikan oleh saksi di persidangan dipandang sebagai alat bukti yang penting ${ }^{6}$ dan utama. Hampir semua pembuktian perkara pidana, selalu didasarkan kepada pemeriksaan keterangan saksi, meskipun keterangan saksi bukan satu-satunya alat bukti namun sekurang-kurangnya di samping pembuktian dengan alat bukti yang lain, masih tetap selalu diperlukan pembuktian dengan alat bukti keterangan saksi.

Saksi yang juga seorang pelaku dalam perkara yang sama dalam praktik peradilan disebut dengan saksi mahkota. Penggunaan saksi mahkota hanya dapat dilihat dalam perkara pidana yang berbentuk penyertaan, dan terhadap perkara pidana tersebut telah dilakukan pemisahan sejak proses pemeriksaan pendahuluan di tingkat penyidikan.

Saksi mahkota adalah saksi yang berasal atau diambil dari salah seorang tersangka atau terdakwa lainnya yang bersama-sama melakukan perbuatan pidana, dan dalam hal mana kepada saksi tersebut diberikan mahkota. Adapun mahkota yang diberikan kepada saksi yang berstatus terdakwa tersebut adalah dalam bentuk ditiadakan penuntutan terhadap perkaranya atau diberikannya suatu tuntutan yang sangat ringan apabila perkaranya dilimpahkan ke pengadilan atau dimaafkan atas kesalahan yang pernah dilakukan. ${ }^{7}$ Ini terlihat di dalam Yurisprudensi Mahkamah Agung No. 1986K/Pid/1989 Tanggal 21 Maret 1990 bahwa "jaksa penuntut umum boleh mengajukan teman terdakwa yang ikut serta dalam pidana sebagai saksi dengan syarat tidak masuk dalam berkas terdakwa pertama".

Selain itu, munculnya dan digunakannya saksi mahkota dalam perkara pidana yang dilakukan pemisahan tersebut didasarkan pada alasan karena kurangnya alat bukti yang diajukan oleh penuntut umum. Dalam perkembangannya, ternyata muncul berbagai pendapat, baik yang berasal dari praktisi maupun akademisi, mengenai penggunaan saksi mahkota sebagai alat bukti dalam pemeriksaan perkara pidana. Sebagian

\footnotetext{
${ }^{5}$ Ibid., 196.

${ }^{6}$ Suryono Sutarto, Hukum Acara Pidana Jilid I(Semarang: Badan Penerbit UNDIP, 1991), 54.

${ }^{7}$ Lilik Mulyadi, Putusan Hakim dalam Hukum Acara Pidana: Teori, Praktik, Teknik Penyusunan dan Permasalahannya (Bandung: Citra Aditya Bakti, 2007), 85-86.
} 
pihak berpendapat bahwa penggunaan saksi mahkota diperbolehkan karena bertujuan untuk tercapainya rasa keadilan publik. Namun sebagian berpendapat bahwa penggunaan saksi mahkota tidak diperbolehkan karena bertentangan dengan hak asasi manusia dan rasa keadilan terdakwa. ${ }^{8}$ Pasal 189 ayat 3 KUHAP menyatakan bahwa, "keterangan terdakwa hanya dapat dipergunakan terhadap dirinya sendiri". ' Ini berarti bahwa terdakwa mempunyai hak untuk tidak mempersalahkan dirinya sendiri sejak proses penyidikan sampai proses persidangan. Jelaslah apabila kedudukan seorang terdakwa dijadikan saksi mahkota itu melanggar hak asasi manusia.

\section{Pembuktian dalam Hukum Acara Pidana Islam}

Pembuktian menurut istilah bahasa Arab berasal dari kata "albayyinah" yang artinya suatu yang menjelaskan. ${ }^{10}$ Secara etimologi berarti keterangan, yaitu segala sesuatu yang dapat menjelaskan hak (benar). Dalam istilah teknis, berarti alat-alat bukti dalam sidang pengadilan. Ulama fiqh membahas alat bukti dalam persoalan pengadilan dengan segala perangkatnya. Dalam fiqh, alat bukti disebut juga turuq al-ithbât. ${ }^{11}$

Al-bayyinah didefinisikan oleh ulama fiqh sesuai dengan pengertian etimologisnya. Jumhur ulama mengartikan al-bayyinah secara sempit, yaitu sama dengan kesaksian. Namun, menurut Ibnu al-Qayyim al-Jauziyah, tokoh fiqh mazhab Hambali, al-bayyinah mengandung pengertian yang lebih luas dari pada pengertian jumhur ulama tersebut, menurutnya, kesaksian hanya salah satu dari jenis al-bayyinah yang dapat digunakan untuk mendukung dakwaan seseorang. Al-bayyinah didefinisikan oleh Ibnu al-Qayyim al-Jauziyah sebagai "segala sesuatu yang dapat digunakan untuk menjelaskan yang hak (benar) di depan majelis hakim, baik berupa keterangan, saksi dan berbagai indikasi yang dapat dijadikan pedoman oleh majelis hakim untuk mengembalikan hak kepada pemiliknya". ${ }^{12}$

\footnotetext{
${ }^{8}$ Dwinanto Agung Wibowo, "Peranan Saksi Mahkota Dalam Peradilan Pidana Di Indonesia", dalam htttp//lontar.ui.ac.id/file?file=digital/20252706-T28577-peranan\%20saksi.pdf, diakses pada 18 Maret 2014.

${ }^{9}$ KUHAP (Kitab Undang-Undang Hukum Acara Pidana).

${ }^{10}$ Sulaikhan Lubis, Hukum Acara perdata Peradilan Agama di Indonesia (Jakarta: Kencana Prenada Media Group, 2005), 135.

${ }^{11}$ Abdul Aziz Dahlan, Ensiklopedi Hukum Islam (Jakarta: Icthtiar Baru Van Hoeve, 1996), 207.

${ }^{12} \mathrm{lbid}$.
} 
Secara terminologis, pembuktian berarti memberikan keterangan dengan dalil sehingga meyakinkan. Beberapa pakar hukum Indonesia memberikan berbagai macam pengertian mengenai pembuktian. Prof. Dr. Supomo misalnya, dalam bukunya, Hukum Acara Pengadilan Negeri, menerangkan bahwa pembuktian mempunyai arti luas dan arti terbatas. Dalam arti luas, pembuktian berarti memperkuat kesimpulan dengan syarat-syarat bukti yang sah, sedangkan dalam arti terbatas pembuktian itu hanya diperlukan apabila yang dikemukan oleh penggugat itu dibantah oleh tergugat. ${ }^{13}$

Secara umum, bukti merupakan sesuatu yang menjelaskan dan mengungkap kebenaran. Al-Qur'an menyebutkan pembuktian tidak hanya dalam arti dua orang saksi. Akan tetapi juga dalam keterangan, dalil, dan alasan, baik secara sendiri-sendiri maupun secara kumulasi. ${ }^{14}$ Sementara itu menurut Sayyid Sabiq, alat bukti dalam dakwaan yaitu: ${ }^{15}$ Ikrar, kesaksian, sumpah dan dokumen resmi.

Mengenai dasar hukum mengenai kewajiban dan adanya perintah pembuktian terdapat pada surat al-Baqarah ayat 282 yang artinya: ${ }^{16}$

“... Dan persaksikanlah dengan dua orang saksi dari orang-orang lelaki (diantaramu). Jika tak ada dua orang lelaki, maka (boleh) seorang lelaki dan dua orang perempuan dari saksi-saksi yang kamu ridhai, supaya jika seorang lupa maka yang seorang mengingatkannya. Janganlah saksi-saksi itu enggan (memberi keterangan) apabila mereka dipanggil..."

\section{Saksi Mahkota dalam Hukum Acara Pidana Islam}

Kesaksian dalam hukum acara pidana Islam dikenal dengan sebutan ash-shahâdah, menurut bahasa artinya antara lain: ${ }^{17}$

1. Pernyataan atau pemberitaan yang asli.

2. Ucapan yang keluar dari pengetahuan yang diperoleh dengan penyaksian langsung.

3. Mengetahui sesuatu secara pasti, mengalami dan melihatnya.

Sedangkan menurut shara', kesaksian adalah pemberitaan yang pasti yaitu ucapan yang keluar yang diperoleh dengan penyaksian

\footnotetext{
${ }^{13}$ Sulaikhan Lubis, Hukum Acara perdata, 136.

${ }^{14}$ Ibnu Qayyim al-Jauziyah, Hukum Acara Peradilan Islam (Yogyakarta: Pustaka Pelajar, 2006), 15.

${ }^{15}$ Sayyid Saabiq, Fikih Sunnah 14, terj Mahyuddun Syaf (Bandung: PT Alma'arif, 1978), 49.

${ }^{16}$ Depag RI, Al-Qur'an dan Terjemahannya (Jakarta: CV Atlas, 1998), 70.

${ }^{17}$ Anshoruddin, Hukum Pembuktian Menurut Hukum Acara Islam dan Hukum Positif(Yogyakarta: Pustaka Pelajar, 2004), 73.
} 
langsung atau dari pengetahuan yang diperoleh dari orang lain karena beritanya telah tersebar. ${ }^{18}$ Dari pengertian ini sudah jelas bagaimana definisi dari kesaksian, yaitu pemberitaan akan hak seseorang atas orang lain dengan lafat kesaksian di depan sidang pengadilan yang diperoleh dari penyaksian langsung bukan karena dugaan atau perkiraan.

Hukum acara pidana Islam tidak membahas secara langsung mengenai saksi mahkota. Saksi mahkota yang kedudukannya merupakan saksi yang meringankan untuk terdakwa dirinya sendiri dan memberatkan untuk terdakwa asal. Artinya, terdakwa kedua sebagai saksi mahkota mendapat keuntungan keringanan hukuman atas persaksian yang diberikannya.

Saksi yang meringankan atau biasa disebut saksi a de charge adalah pengajuan saksi atau seseorang yang memiliki keahlian khusus guna untuk memberikan keterangan yang menguntungkan bagi terdakwa. ${ }^{19}$ Pengajuan saksi yang menguntungkan bagi terdakwa bukan hanya sebatas sebagai hak, tetapi sesuatu hal yang harus dimunculkan oleh penyidik.

Saksi yang meringankan dan saksi yang memberatkan ini terjadi dalam saksi mahkota, yaitu kesaksian antara seorang terdakwa dengan terdakwa lainnya yang bersama-sama melakukan tindak pidana kejahatan, pada saat itu dijadikan saksi dan pada saat yang lainnya dijadikan terdakwa. Dalam hukum acara pidana Indonesia saksi mahkota dapat dijadikan sebagai alat bukti saksi, disebabkan karena saksi adalah terdakwa dalam beberapa perkara yang dipisah dengan dakwaan yang sama.

Penggunaan saksi mahkota dalam hukum acara menjadi alternatif bagi hakim sebagai alat bukti saksi dalam mengungkap dan memutuskan suatu perkara tindak pidana. Dasar hukum saksi mahkota tidak diatur secara tegas dalam KUHAP (Kitab Undang-undang Hukum Acara Pidana), namun KUHAP tidak melarang penggunaan saksi mahkota, Pasal 142 KUHAP menjadi alasan penggunaan saksi mahkota bagi hakim di pengadilan untuk memeriksa masing-masing terdakwa secara terpisah. ${ }^{20}$

\footnotetext{
${ }^{18} \mathrm{lbid}$.

${ }^{19}$ Hendar Soetarna, Hukum Pembuktian dalam Acara Pidana (Bandung: PT Alumni, 2011), 67.

20 Jonizul Hendra "Renungan Saksi Mahkota dalam Islam", dalam http://jonizulhendra.blogspot.com/2014/02/normal-0-false-false-false-en-us-x-none.html, diakses pada 12 Juni 2014.
} 
Dalam hukum Islam, salah satu syarat saksi adalah adil. Maka dari itu keberadaan saksi mahkota sebagai alat bukti dalam penyelesaian perkara pidana yang merupakan kesaksian antara terdakwa dengan terdakwa yang lain harus berada di bawah sumpah, dalam arti bahwa saksi yang tertuduh telah melakukan kemaksiatan.

Pembahasan tentang keberadaan saksi mahkota sebagai alat bukti dalam penyelesaian perkara pidana dalam kitab klasik tidak ditemukan, karena memang praktek penggunaan saksi mahkota sebagai alat bukti belum dikenal ketika itu. Namun apabila saksi mahkota dibutuhkan sebagai alat bukti dalam mengungkap suatu perkara pidana tanpa adanya alat bukti lain yang mendukung, maka saksi mahkota dibolehkan. Hal ini dihukumi darûrât, karena tidak terdapat alat bukti lain selain saksi mahkota yang mengetahui perkara tersebut dan atas pertimbangan hakim kesaksian diterima dalam rangka mencari kemaslahatan dan keputusan yang adil..$^{21}$

Konsep ḍarûrât dalam hukum Islam diperbolehkan, sesuai dengan dalil kaidah fiqhiyah yaitu: ${ }^{22}$

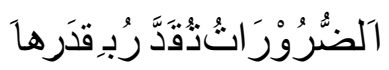

"Sesuatu yang diperbolehkan karena darûrât, harus diperkirakan menurut batasan ukuran kebutuhan minimal."

Kaidah di atas sesungguhnya membatasi manusia dalam melakukan yang dilarang karena kondisi d̦arûrât. Seperti telah dijelaskan melakukan yang haram karena ḍarûrât tidak boleh melampaui batas, tetapi hanya sekedarnya. Oleh sebab itu, jika kemudharatan atau keadaan yang memaksa tersebut sudah hilang, maka hukum kebolehan yang berdasarkan kemudharatan menjadi hilang juga, artinya perbuatan boleh kembali keasal semula, yaitu terlarang. ${ }^{23}$

Dari adanya kaidah tersebut, maka muncul kaidah sebagai berikut:

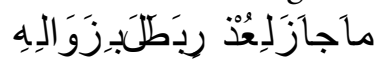

"Apa saja kebolehannya karena ada alasan kuat ("udhr), maka hilangnya kebolehan itu disebabkan oleh hilangnya alasan."

Sebagai contoh dalam hal ini adalah perampokan di laut (bajak laut) terhadap kelompok yang lainnya juga merampok dan untuk

\footnotetext{
${ }^{21}$ lbid.

22 Djazuli, Kaidah-Kaidah Fiqih, Kaidah-Kaidah Hukum Islam dalam Menyelesaikan MasalahMasalah yang Praktis (Jakarta: Pranada Media Grup, 2007), 73.

${ }^{23}$ Muhammad Mas'ud Zein, Sistematika Teori Hukum Islam (Qawâ'id-Fiqhiyyah) (Jawa Timur: AlSyarîfah Al-Khadîzah, 2006), 66.
} 
kesaksiannya diterima dari kelompok perampok itu, karena hanya kelompok itulah yang mengetahui terhadap suatu peristiwa yang mereka lakukan. Akan tetapi penggunaan saksi mahkota sebagai alat bukti, jika ada alat bukti lain, seperti saksi yang memadai, pengakuan/alat bukti yang tertulis dan sumpah, maka saksi mahkota ditinggalkan karena syarat keadilan tidak terpenuhi oleh saksi mahkota.

\section{Kedudukan Saksi Mahkota dalam Peradilan di Indonesia}

Dalam Undang-Undang tidak dijumpai apa yang disebut dengan saksi mahkota, tetapi dalam kenyataannya saksi mahkota ini ada dalam praktik persidangan. Adapun mengenai siapa dan apa yang dimaksud dengan saksi mahkota berikut ini pendapat para sarjana, yaitu antara lain:

1. R. Soesilo ${ }^{24}$

Saksi mahkota adalah saksi yang ditampilkan dari beberapa terdakwa/salah seorang terdakwa guna membuktikan kesalahan terdakwa yang dituntut. Saksi mahkota dapat dibebaskan dari penuntutan pidana atau kemudian akan dituntut pidana secara tersendiri, tergantung dari kebijaksanaan penuntut umum yang bersangkutan.

2. Andi Hamzah ${ }^{25}$

Saksi mahkota adalah salah seorang terdakwa dijadikan (dilantik) menjadi saksi, jadi diberi mahkota, yang tidak akan dijadikan terdakwa lagi atau lebih mudahnya bahwa saksi mahkota adalah seorang terdakwa menjadi saksi bagi terdakwa lainnya yang kedudukannya sebagai terdakwa dilepaskan.

Biasanya saksi mahkota adalah terdakwa yang paling ringan hukumnnya. Pengubahan status terdakwa menjadi saksi itulah yang dianggap sebagai pemberian mahkota "saksi" (seperti dinobatkan menjadi saksi). Biasanya jaksa memilih terdakwa yang paling ringan kesalahannya atau yang paling "kurang dosa" nya menjadi saksi. Misalnya beberapa orang melakukan perjudian togel bersama-sama. Ada yang menjual nomor dan ada yang membeli nomor togelnya.

Saksi kunci yang diajukan oleh jaksa penuntut umum dimana tanpa saksi itu jaksa penuntut umum tidak mempunyai bukti. Jadi jatuh bangunnya dakwaan jaksa penuntut umum sangat tergantung dari saksi

\footnotetext{
${ }^{24}$ R. Soesilo, Teknik Berita Acara (Proses Verbal) Ilmu Bukti dan Laporan (Bogor: Politea, 1980), 7.

${ }^{25}$ Andi Hamzah, Hukum Acara Pidana Indonesia, 15.
} 
mahkota. Disebut saksi mahkota yang merupakan penerjemahan secara langsung dari kroon artinya mahkota dan getuige artinya saksi. Jadi ia seperti perlambangan raja, menjadi saksi utama yang mewakili Negara atau kerajaan. Bisa saja saksi mahkota itu bukan pelaku kejahatan, namun pada umumnya saksi mahkota adalah "orang dalam". Jika ia adalah pelaku kejahatan maka sering disebut dengan whistle blower atau disebut pembocor rahasia.

Dalam praktik peradilan di Indonesia saat ini, saksi mahkota diartikan sebagai terdakwa yang berstatus menjadi saksi dalam perkara terdakwa lain. Menurut kamus Indonesia-Belanda, ${ }^{26}$ kata "split" atau lengkapnya "splitsing" merupakan kata yang berarti "pemisahan". Splitsing sudah dikenal sejak sebelum berlakunya KUHAP atau saat masih berlakunya HIR sebagai landasan hukum acara pidana.

Kebalikan dari pemisahan berkas perkara (splitsing van zaken) adalah penggabungan berkas perkara (voeging van zaken) menurut Moeljatno diartikan sebagai "penyatuan", yaitu beberapa perkara disatukan pemeriksaannya dalam sidang pengadilan. ${ }^{27}$

Perbedaan dari penggabungan dan pemisahan berkas perkara terletak pada tindak pidana yang dilakukannya. Pasal 141 KUHAP itu mensyaratkan hanya satu tindak pidana yang dilakukan, akan tetapi pemisahan berkas perkara dilakukan apabila tindak pidana tesebut lebih dari satu dan jenisnya berbeda pula.

Di dalam KUHAP, pemisahan berkas perkara ketentuannya dicantumkan dalam Pasal 142 KUHAP yang menyatakan bahwa "dalam hal penuntutan umum menerima satu berkas perkara yang memuat beberapa tindak pidana yang dilakukan oleh beberapa orang tersangka yang tidak termasuk dalam ketentuan Pasal 141, penuntut umum dapat melakukan penuntutan terhadap masing-masng terdakwa secara terpisah".

Dari bunyi Pasal 142 KUHAP dapat diambil kesimpulan bahwa untuk melakukan pemisahan berkas perkara harus dipenuhi syarat-syarat sebagai berikut:

a. Satu berkas perkara.

b. Memuat beberapa tindak pidana.

${ }^{26}$ Dwinanto Agung Wibowo, "Peranan Saksi Mahkota Dalam Peradilan Pidana Di Indonesia", dalam htttp//lontar.ui.ac.id/file?file=digital/20252706-T28577-peranan\%20saksi.pdf, diakses pada 18 Maret 2014.

${ }^{27}$ Moeljatno, Hukum Acara Pidana (Yogyakarta: UGM), 87. 
c. Dilakukan oleh beberapa tersangka.

d. Dan tidak termasuk dalam ketentuan Pasal 141 KUHAP.

Dalam praktik, tidak jarang dijumpai terjadi pemisahan berkas perkara di luar yang diisyaratkan ketentuan Pasal 142 KUHAP. Penuntut umum menerima satu berkas perkara di dalamnya hanya memuat satu tindak pidana yang dilakukan secara bersama-sama oleh beberapa tersangka. Pemisahan baru dilakukan ketika penuntut umum tidak dapat menghadirkan sebagian terdakwa di persidangan setelah memanggil tiga kali berturut-turut dengan cara mengajukan permohonan kepada majelis hakim yang memeriksa perkara, bahwa terdakwa tidak hadir. Dipisahkan perkaranya karena dituntut secara sendiri. Jadi pemisahan berkas perkara dapat didasarkan kepada kepentingan pemeriksaan semata-mata.

Dalam pemisahan berkas perkara inilah tindakan menjadikan para tersangka untuk saling menjadi saksi. Pemisahan berkas perkara tersebut dilakukan terhadap beberapa tindak pidana yang dilakukan oleh beberapa orang tersangka, namun kebiasaan yang terjadi dalam praktik sepanjang pengamatan peneliti, biasanya setelah jaksa menerima berkas perkara dari penyidik dengan kondisi terdapat satu tindak pidana yang dilakukan oleh beberapa orang tersangka, jaksa penuntut umum memberikan petunjuk kepada penyidik untuk memisahkan berkas perkara tersebut.

Pada dasarnya, pemisahan berkas perkara terjadi disebabkan faktor pelaku tindak pidana yang terdiri dari beberapa orang apabila terdakwa terdiri dari beberapa orang penuntut umum dapat menempuh cara untuk memisahkan berkas perkara menjadi beberapa berkas perkara sesuai dengan jumlah terdakwanya, sehingga:

a. Berkas yang semula diterima penuntut umum dari penyidik, dipisah menjadi dua atau beberapa berkas perkara.

b. Pemisahan dilakukan apabila yang menjadi terdakwa dalam perkara tersebut, terdiri dari beberapa orang. Dengan pemisahan berkas perkara dimaksud, masing-masing terdakwa didakwa dalam satu surat dakwaan yang berdiri sendiri antara yang satu dengan yang lain.

c. Pemeriksaan perkara dalam pemisahan berkas perkara, tidak lagi dilakukan bersamaan dengan suatu persidangan. Masing-masing terdakwa diperiksa dalam persidangan yang berbeda. 
d. Pada umumnya, pemisahan berkas perkara menjadi penting, apabila dalam perkara tersebut kurang bukti dan kesaksian atau kurangnya alat bukti.

Deskripsi Putusan Pengadilan Negeri Bangkalan No:216/Pid.B/2012/PN.Bkl. tentang Penggunaan Saksi Mahkota dalam Proses Pembuktian Tindak Pidana Perjudian

1. Duduk Perkara

Pada hari Kamis tertanggal 18 Oktober 2012 sekitar jam 14:00 WIB bertempat di sebuah gardu Dusun Serpek Desa Dlemer Kec. Kwanyar Kab. Bangkalan, terdakwa Imam bin Sairi dengan tanpa izin sengaja menawarkan atau memberi kesempatan kepada khalayak umum untuk bermain judi togel, dalam hal ini terdakwa membeli nomer togel kepada saksi Moh. Moner yang dalam perkara ini dilakukan penuntutan terpisah (saksi mahkota). Berawal ketika terdakwa membeli atau menombok angka judi togel kepada saksi Moh. Moner selaku pengecer yakni angka 65 sebesar Rp. 10.000, angka 35 sebesar Rp.10.000 angka 12 sebesar Rp. 16.000 angka 17 sebesar Rp. 20.000 jadi totalnya Rp. 56.000 dimana terdakwa melakukan permainan judi togel dengan cara mengirimkan SMS kepada saksi Moh. Moner, selanjutnya terdakwa mendatangi saksi Moh. Moner dan membayar sebesar Rp. 50.000 sedangkan untuk sisanya tersangka akan membayar pada hari Jum'at dan pemainan judi togel tersebut apabila ada penombok yang cocok dengan nomor tombokannya maka untuk 2 angka besar tombokan Rp. 1.000 maka akan mendapatkan bayaran Rp. 60.000 untuk 3 angka dengan besar tombokan Rp. 1.000 maka akan mendapatkan Rp. 300.000 untuk angka 4 dengan besar tombokan Rp. 1.000 maka akan mendapatkan Rp. 2.000 .000 dan semuanya tergantung besar kecilnya tombokan dan minimal Rp. 1.000.

Ketika terdakwa sedang membayar tombokannya kepada saksi Moh. Moner tiba-tiba datang saksi R. Eka Arietya, SH, Mudakin dan Hendro Puji $S$ melakukan penangkapan terhadap terdakwa dan saksi Moh. Moner, dan selanjutnya mereka dibawa ke Polres Bangkalan untuk proses lebih lanjut. 
Bahwasanya permainan judi togel tersebut pengharapan untuk menang dan tergantung pada untung-untungan saja dan terdakwa diancam pidana dalam Pasal 303 (1) ke 2 KUHP.

Dalam proses pembuktian hakim Pengadilan Negeri Bangkalan, terdapat kekurangan alat bukti meskipun ada sekurangkurangnya dua alat bukti. Untuk mencapai suatu pembuktian, maka penuntut umum mengangkat saksi Moh. Moner, yang kedudukannya sebagai terdakwa dalam berita acara penyidikan berbeda, dijadikan sebagai saksi mahkota.

2. Dakwaan

a. Dakwaan Primair

Pada hari Kamis, tanggal 18 Oktober 2012 telah terjadi sebuah kejadian tindak pidana perjudian togel di sebuah gardu pinggir jalan tepatnya di Dusun Serpek, Desa Dlemer, Kec. Kwanyar, Kab. Bangkalan, kejadian dengan terdakwa Imam bin Sairi ini terjadi sekitar siang hari jam 14.00 WIB yang mana daerah kejadian masih termasuk dalam daerah hukum Pengadilan Bangkalan. Terdakwa didakwa karena telah melakukan penawaran tanpa izin atau memberi kesempatan kepada masyarakat sekitar untuk bermain judi togel, atau dengan sengaja turut serta dan kerja sama dalam perusahaan dengan menggunakan syarat-syarat dalam permainannya. Adapun terdakwa sendiri sadar bahwa kemungkinan untuk menang hanya tergantung pada keuntungan belaka, karena dikira para pemain dianggap lebih terlatih dalam memainkan pertaruhan judi togel tersebut. Adapun perbuatan terdakwa dilakukan dengan beberapa cara sebagai berikut:

1) Terdakwa membeli atau menombok angka judi togel kepada temannya yang merupakan saksi mahkota yaitu Moh. Moner (yang penuntutannya dilakukan secara terpisah) selaku pengecer dengan cara mengirimkan SMS yakni angka 65 sebesar Rp. 10.000, angka 35 sebesar Rp.10.000 angka 12 sebesar Rp. 16.000 angka 17 sebesar Rp. 20.000 jadi totalnya Rp. 56.000. Selanjutnya terdakwa mendatangi saksi Moh. Moner ke gardu pinggir jalan Desa Dlemer, Kec. Kwanyar, Kab. Bangkalan dengan membayar uang sebesar Rp. 50.000 sedangkan untuk sisanya tersangka akan membayar pada hari Jum'at. Dalam pemainan judi togel tersebut apabila ada penombok yang cocok dengan nomor tombokannya maka untuk 2 angka besar 
tombokan Rp. 1.000 maka akan mendapatkan bayaran Rp. 60.000 untuk 3 angka dengan besar tombokan Rp. 1.000 maka akan mendapatkan Rp. 300.000 untuk angka 4 dengan besar tombokan Rp. 1.000 maka akan mendapatkan Rp. 2.000.000 dan semuanya tergantung besar kecilnya tombokan dan minimal Rp. 1.000 .

2) Setelah perundingan keduanya selesai, terdakwa menemui saksi Moh. Moner di derah tempat kejadian penangkapan berlangsung untuk membayar tombokannya. Tetapi secara tiba-tiba datang saksi R. Eka Arietya, SH, Mudakin dan Hendro Puji S melakukan penangkapan terhadap terdakwa dan saksi Moh. Moner, dan selanjutnya mereka dibawa ke Polres Bangkalan untuk proses lebih lanjut.

3) Bahwasanya untuk memenangkan permainan judi togel hanya tergantung pada pengharapan keuntungan masing-masing pihak saja, dan terdawa dalam melakukan perjudian ini tanpa dilengkapi izin dari pihak yang berwenang.

4) Perbuatan terdakwa sebagaimana diatur dan diancam pidana dalam Pasal 302 (1) ke 2 KUHP.

b. Subsidair

1) Sebagaimana dalam dakwaan primair, bahwa terdakwa Imam Bin Sairi pada suatu waktu dan tempat yang masih dalam ruang lingkup lingkungan masyarakat Bangkalan telah melakukan perminan judi togel, terdakwa sendiri sadar bahwa kemungkinan untuk menang hanya tergantung pada keuntungan belaka, karena dikira para pemain dianggap lebih terlatih dalam memainkan pertaruhan judi togel tersebut, demikian juga segala peruntungan lainnya kecuali jika ada izin dari penguasa yang berwenang. Perbuatan tersebut dilakukan oleh terdakwa dengan cara sebagai berikut: ketika terdakwa membeli atau menombok angka judi togel kepada temannya yang merupakan saksi mahkota yaitu Moh. Moner (yang penuntutannya dilakukan secara terpisah) selaku pengecer dengan cara mengirimkan SMS yakni angka 65 sebesar Rp. 10.000, angka 35 sebesar Rp. 10.000 angka 12 sebesar Rp. 16.000 angka 17 sebesar Rp. 20.000 jadi totalnya Rp. 56.000. Selanjutnya terdakwa mendatangi saksi Moh. Moner ke gardu pinggir jalan Desa Dlemer, Kec. Kwanyar, Kab. Bangkalan 
dengan membayar uang sebesar Rp. 50.000 sedangkan untuk sisanya tersangka akan membayar pada hari Jum'at. Dalam pemainan judi togel tersebut apabila ada penombok yang cocok dengan nomor tombokannya maka untuk 2 angka besar tombokan Rp. 1.000 maka akan mendapatkan bayaran Rp. 60.000 untuk 3 angka dengan besar tombokan Rp. 1.000 maka akan mendapatkan Rp. 300.000 untuk angka 4 dengan besar tombokan Rp. 1.000 maka akan mendapatkan Rp. 2.000.000 dan semuanya tergantung besar kecilnya tombokan dan minimal $\mathrm{Rp}$. 1.000 .

2) Setelah perundingan keduanya selesai, terdakwa menemui saksi Moh. Moner di derah tempat kejadian penangkapan berlangsung untuk membayar tombokannya. Tetapi secara tiba-tiba datang saksi R. Eka Arietya, SH, Mudakin dan Hendro Puji S melakukan penangkapan terhadap terdakwa dan saksi Moh. Moner, dan selanjutnya mereka dibawa ke Polres Bangkalan untuk proses lebih lanjut.

3) Bahwasanya untuk memenangkan permainan judi togel hanya tergantung pada pengharapan keuntungan masing-masing pihak saja, dan terdawa dalam melakukan perjudian ini tanpa dilengkapi izin dari pihak yang berwenang.

4) Perbuatan terdakwa sebagaimana diatur dan diancam pidana dalam Pasal 303 (1) ke 2 KUHP.

3. Putusan

a. Menyatakan terdakwa Imam Bin Sairi tidak terbukti bersalah melakukan tindak pidana, yaitu "tanpa izin dengan sengaja menawarkan atau memberikan kesempatan kepada khalayak umum untuk bermain judi atau dengan sengaja turut serta dalam perusahaan untuk itu dengan tidak peduli apakah untuk menggunakan kesempatan adanya sesuatu syarat atau dipenuhinya sesuatu tata cara" sebagaimana diatur dan diancam pidana Pasal 303 bis Ayat (1) ke 2 seperti dalam surat dakwaan primair.

b. Menyatakan terdakwa Imam bin Sairi terbukti bersalah melakukan tindak pidana "dengan sengaja ikut serta permainan judi di jalan umum atau di pinggirnya maupun di tempat yang dapat dimasuki khalayak umum, kecuali jika untuk mengadakan itu ada izin dari penguasa yang berwenang" sebagaimana diatur 
dan diancam pidana Pasal 303 Ayat (1) ke 2 KUHAP sebagaimana diuraikan dalam dakwaan subsidair.

c. Menjatuhkan pidana penjara terhadap terdakwa Imam bin Sairi dengan pidana selama 5 (lima) bulan dikurangi selama terdakwa berada dalam tahanan dan dengan perintah agar terdakwa tetap dalam tahanan.

d. Menyatakan barang bukti berupa: sebuah HP merk Cross type GG 52 T warna putih dengan kartu XL 08191359939 yang di dalamnya terdapat tombokan angka togel beserta besarnya tombokan dirampas untuk dimusnahkan.

e. Menetapkan supaya terdakwa dibebani biaya perkara sebesar Rp. 2.000 (dua ribu rupiah). ${ }^{28}$

\section{Pertimbangan Hakim terhadap Penggunaan Saksi Mahkota dalam Proses Pembuktian Tindak Pidana Perjudian}

Dalam praktik hukum acara pidana, saksi mahkota merupakan penerapan Pasal $143 \mathrm{KUHAP}^{29}$ yang antara tersangka atau terdakwa yang satu dengan yang lainnya dipisahkan berkas perkaranya (spilitsing) atau dengan kata lain, tidak dijadikan dalam satu berkas perkara. Konsekuensi atas pemisahan berkas perkara itu maka masing-masing tersangka atau terdakwa disidangkan secara tersendiri, yang mana terdakwa yang satu memberikan kesaksian dalam persidangan terdakwa lainnya begitu pula sebaliknya, dan kesaksian yang diberikan oleh masing-masing terdakwa saat menjadi saksi yang diupayakan menjadi alat bukti keterangan saksi atau dapat pula berupa alat bukti surat jika dalam penyidikan telah memberikan keterangan di bawah sumpah.

Ini terjadi dalam kasus tindak pidana perjudian (putusan No.216/Pid.B/PN.Bkl), dimana hakim menggunakan saksi Moh. Moner atas terdakwa Imam bin Sairi. Hakim mengangkat Moh. Moner sebagai saksi mahkota karena beberapa alasan, yaitu kurangnya alat bukti dalam persidangan, sebagai petunjuk hakim dalam memutus perkara dan dibenarkan dalam Yurisprudensi Mahkamah Agung No. 1986K/Pid/1989 Tanggal 21 Maret 1990 bahwa "jaksa penuntut umum boleh mengajukan teman terdakwa yang ikut serta dalam pidana sebagai saksi dengan syarat tidak masuk dalam berkas terdakwa pertama”.

\footnotetext{
${ }^{28}$ Kutipan Putusan No.216/Pid.B/PN.Bkl, Tanggal 23Desember 2013.

${ }^{29}$ KUHAP (Kitab Undang-Undang Hukum Acara Pidana).
} 
Kedudukan saksi mahkota dalam kasus ini ialah memperberat terdakwa karena terdakwa merasa terpojok atas kesaksiaan saksi yang berada di bawah sumpah. Saksi mahkota ini akan mengajukan persaksiannya secara benar karena konsekuensinya dia akan diringankan pidananya.

Dalam kasus ini Moh. Moner sebagai saksi mahkota dibenarkan dalam Undang-Undang. Menurut Pasal 1 Ayat $27 \mathrm{KUHAP}^{30}$, yang dimaksud keterangan saksi adalah salah satu alat bukti dalam perkara pidana yang berupa keterangan saksi mengenai suatu peristiwa pidana yang ia dengar sendiri, ia lihat sendiri dan ia alami sendiri dengan menyebut alasan dari pengetahuan itu". Sedangkan saksi Moh. Moner di sini merupakan alat bukti kunci untuk bisa mengadili terdakwa tindak pidana perjudian yakni Imam bin Sairi.

Adapun persaksian Moh. Moner sebagai saksi mahkota dalam kasus tindak pidana perjudian dalam putusan No.216/Pid.B/PN.Bkl dan dibenarkan oleh majelis hakim ialah:

a. Bahwa perkara yang dihadapi oleh terdakwa berhubungan dengan permainan judi togel.

b. Bahwa kejadiannya pada hari Kamis tanggal 18 Oktober 2012, sekitar pukul 14.00 WIB di gardu pinggir jalan Dusun Serpek Timur, Desa Dlemer, Kec. Kwanyar, Kab. Bangkalan.

c. Bakwa saksi menjual nomor judi togel baru 1 (satu) bulan.

d. Bahwa saksi menjual nomor judi togel mulai dari 2 angka, 3 angka dan 4 angka dan yang 2 angka mendapat Rp. 60.000, kalau 3 angka mendapat Rp. 300.000 dan kalau 4 angka mendapat Rp. 2.000.000.

e. Bahwa ketika saksi ditangkap ada 1 orang yang membeli yaitu Imam (perkara split).

f. Bahwa cara saksi menjual kalau ada orang beli saya tulis di kertas rangkap.

g. Bahwa saksi sebagai penjual togel.

h. Bahwa saksi dapat komisi Rp. 15.000 tiap pengeluaran.

i. Bahwa setiap minggunya 5 kali pengeluaran hari Senin, Rabu, Kamis, Sabtu, dan Minggu.

j. Bahwa saksi tahunya dari Mohyi dan didapat dari Negara Singapura.

${ }^{30} \mathrm{Ibid} ; 179$. 
k. Bahwa selama saya menjual nomor judi togel ada yang dapat.

1. Bahwa saksi menyetor ke Mohyi.

$\mathrm{m}$. Bahwa saksi tidak punya izin dari yang berwajib menjual nomor judi togel.

n. Bahwa saksi merasa bersalah dan menyesal serta tidak akan mengulangi lagi. ${ }^{31}$

Dari persaksian tersebut semuanya dibenarkan dan keterangan saksi mahkota jelas benar dan tidak keberatan. Inilah alasan dan pertimbangan hakim mengangkat saksi mahkota dalam kasus perjudian dengan putusan No.216/Pid.B/PN.Bkl.

Analisis Putusan Pengadilan Negeri Bangkalan No: 216/Pid.B/2012/PN.Bkl. terhadap Penggunaan Saksi Mahkota dalam Proses Pembuktian Tindak Pidana Perjudian

Pada umumnya, semua orang dapat dijadikan saksi. Kekecualian menjadi saksi tercantum dalam Pasal 168 Kitab Undang-Undang Hukum Acara Pidana yaitu: ${ }^{32}$

1. Keluarga sedarah atau semeda dalam garis lurus ke atas atau ke bawah sampai derajat ketiga dari terdakwa atau yang bersamasama sebagai terdakwa.

2. Saudara dari terdakwa atau yang bersama-sama sebagai terdakwa, saudara ibu atau saudara bapak, juga mereka yang mempunyai hubungan karena perkawinan, dan anak-anak saudara terdakwa sampai derajat ketiga.

3. Suami atau istri terdakwa meskipun sudah bercerai atau yang bersama-sama sebagai terdakwa.

Dalam penjelasan Pasal 168 KUHAP dikatakan "cukup jelas", padahal ada masalah yang timbul yang berhubungan dengan ketentuan tersebut, yaitu dalam hal "bersama-sama sebagai terdakwa". Secara normatif kata-kata "bersama-sama sebagai terdakwa" terjadi dalam tidak pidana penyertaan yang dilakukan para terdakwa, dan kemungkinan penuntut umum melakukan pemisahan perkara.

Pemisahan perkara dibenarkan oleh Undang-Undang, dan dimaksudkan agar pembuktian lebih mudah karena terdakwa dalam hal satu perkara bisa dijadikan saksi, dan sebaliknya dalam perkara lain yang

\footnotetext{
${ }^{31}$ Kutipan Putusan No.216/Pid.B/PN.Bkl, Tanggal 23 Desember 2013.

${ }^{32}$ Andi Hamzah, Hukum Acara Pidana Indonesia, (Jakarta: Sinar Grafika, 2008), 260.
} 
dipecah tersebut akan berstatus sebagai terdakwa. ${ }^{33}$ Inilah yang dimaksudkan sebagai saksi terdakwa kedua yang disebut sebagai saksi mahkota.

Adanya penggunaan saksi mahkota sebagai alat bukti dalam perkara pidana. tentunya akan menimbulkan berbagai permasalahan yuridis. Ini jelas dilarang dan dikecualikan dalam KUHAP bahwa semua orang bisa menjadi saksi kecuali yang bersama-sama dengan terdakwa. Munculnya alasan untuk memenuhi dan mencapai rasa keadilan publik sebagai dasar argumentasi diajukannya saksi mahkota, bukan merupakan hal yang menjustifikasi penggunaan saksi mahkota sebagai alat bukti, tetapi ini merupakan pemudahan dalam pembuktian yang dilakukan oleh hakim.

Tidak jarang dalam berbagai putusan di Pengadilan Negeri mengangkat saksi mahkota, salah satunya Pengadilan Negeri Bangkalan mengangkat saksi mahkota dalam kasus perjudian dengan putusan No.216/Pid.B/2012/PN.Bkl. Dalam kasus ini hakim mengangkat saksi Moh. Moner (saksi mahkota) atas terdakwa Imam bin Sairi. Hakim mengangkat Moh. Moner sebagai saksi mahkota karena kurangnya alat bukti dalam persidangan. Kedudukan saksi mahkota dalam kasus ini ialah memperberat terdakwa karena terdakwa merasa terpojok atas kesaksiaan saksi yang berada di bawah sumpah. Saksi mahkota ini akan mengajukan persaksiannya secara benar karena konsekuensinya dia akan diringankan pidananya.

Dalam kasus ini Moh. Moner sebagai saksi mahkota dibenarkan dalam Undang-Undang. Menurut Pasal 1 Ayat 27 KUHAP $^{34}$, yang dimaksud keterangan saksi adalah salah satu alat bukti dalam perkara pidana yang berupa keterangan saksi mengenai suatu peristiwa pidana yang ia dengar sendiri, ia lihat sendiri dan ia alami sendiri dengan menyebut alasan dari pengetahuan itu". Sedangkan saksi Moner di sini merupakan alat bukti kunci untuk bisa mengadili terdakwa tindak pidana perjudian yakni Imam bin Sairi.

Hakim Pengadilan Negeri Bangkalan membenarkan penggunaan saksi mahkota ini, karena sesuai dengan Yurisprudensi Mahkamah Agung No. 1986K/Pid/1989 Tanggal 21 Maret 1990 bahwa “jaksa penuntut umum boleh mengajukan teman terdakwa yang ikut serta

\footnotetext{
${ }^{33}$ Hendar Soetarna, Hukum Pembuktian Dalam Acara Pidana, (Bandung: PT Alumni, 2011), 64.

${ }^{34}$ KUHAP (Kitab Undang-Undang Hukum Acara Pidana).
} 
dalam pidana sebagai saksi dengan syarat tidak masuk dalam berkas terdakwa pertama”.

Tetapi dalam Pasal 189 ayat 3 KUHAP menyatakan bahwa, "keterangan terdakwa hanya dapat dipergunakan terhadap dirinya sendiri". ${ }^{35}$ Ini berarti bahwa terdakwa mempunyai hak untuk tidak mempersalahkan dirinya sendiri sejak proses penyidikan sampai proses persidangan. Inilah mengapa saksi mahkota diperdebatkan keberadaannya, dalam pasal ini sudah jelas bahwa terdakwa tidak boleh mempersaksikan persaksiannya untuk orang lain karena secara tidak langsung dia telah mempersaksikan dirinya sendiri melakukan tindak pidana yang didakwakan kepada terdakwa pertama.

Adapun secara normatif, penggunaan saksi mahkota merupakan hal yang sangat bertentangan dengan prinsip-prinsip peradilan yang adil dan tidak memihak (fair trial) dan juga merupakan pelanggaran terhadap kaidah hak asasi manusia sebagaimana yang diatur dalam KUHAP sebagai instrumen hukum nasional dan International Covenant on Civil and Political Rights (ICCPR) tahun 1996 sebagai instrumen hak asasi manusia internasional. Dalam kaitannya dengan penilaian implementasi prinsip-prinsip fair trial maka ICCPR digunakan sebagai instrumen acuan. $^{36}$ Adapun bentuk-bentuk pelanggaran tersebut adalah sebagai berikut:

1. Bahwa saksi mahkota, secara esensinya adalah berstatus terdakwa,. Oleh karena itu, sebagai terdakwa maka pelaku memiliki hak absolut untuk diam atau bahkan hak absolut untuk memberikan jawaban yang bersifat ingkar atau berbohong. Hal ini merupakan konsekuensi yang melekat sebagai akibat dari tidak diwajibkannya terdakwa untuk mengucapkan sumpah dalam memberikan keterangannya. Selain itu, menurut ketentuan Pasal 66 KUHAP dijelaskan bahwa terdakwa tidak memiliki beban pembuktian, namun sebaliknya bahwa beban pembuktian untuk membuktikan kesalahan terdakwa terletak pada pihak jaksa penuntut umum.

2. Bahwa dikarenakan terdakwa tidak dikenakan kewajiban untuk bersumpah maka terdakwa bebas untuk memberikan keterangannya di hadapan persidangan. Sebaliknya, dalam hal terdakwa diajukan

\footnotetext{
${ }^{35} \mathrm{Ibid} ; 236$.

36 Setiyono, "Eksistensi Saksi Mahkota sebagai Alat Bukti dalam Perkara Pidana" dalam http://mmsconsulting.wordpress.com/2008/07/31/eksistensi-saksi-mahkota-sebagai-alat-buktidalam-perkara-pidana/ diakses pada 14 Juni 2014
} 
sebagai saksi mahkota, tentunya terdakwa tidak dapat memberikan keterangan secara bebas karena terikat dengan kewajiban untuk bersumpah. Konsekuensi dari adanya pelanggaran terhadap sumpah tersebut maka terdakwa akan dikenakan atau diancam dengan dakwaan baru berupa tindak pidana kesaksian palsu sebagaimana yang diatur dalam Pasal 242 Kitab Undang-Undang Hukum Pidana. Adanya keterikatan dengan sumpah tersebut maka tentunya akan menimbulkan tekanan psikologis bagi terdakwa karena terdakwa tidak dapat lagi menggunakan hak ingkarnya untuk berbohong.

3. Bahwa sebagai pihak yang berstatus terdakwa walaupun dalam perkara lainnya diberikan kostum sebagai saksi maka pada prinsipnya keterangan yang diberikan oleh terdakwa (saksi mahkota) hanya dapat digunakan terhadap dirinya sendiri. Hal ini sebagaimana yang dijelaskan dalam ketentuan Pasal 189 ayat (3) KUHAP.

4. Bahwa dalam perkembangannya, ternyata Mahkamah Agung memiliki pendapat terbaru tentang penggunaan saksi mahkota dalam suatu perkara pidana dalam hal mana dijelaskan bahwa penggunaan saksi mahkota adalah bertentangan dengan hukum acara pidana yang menjunjung tinggi hak asasi manusia. Hal tersebut sebagaimana dijelaskan dalam Yurisprudensi Mahkamah Agung Republik Indonesia Nomor $1174 \mathrm{~K} / \mathrm{Pid} / 1994$ tanggal 3 Mei 1995, Yurisprudensi Mahkamah Agung Republik Indonesia Nomor 1952 K/Pid/1994 tanggal 29 April 1995, Yurisprudensi Mahkamah Agung Republik Indonesia Nomor 1590 K/Pid/1995 tanggal 3 Mei 1995 dan Yurisprudensi Mahkamah Agung Republik Indonesia Nomor $1592 \mathrm{~K} / \mathrm{Pid} / 1995$ tanggal 3 Mei 1995.

Terlepas dari permasalahan, dimungkinkan terdakwa dapat dijadikan saksi, tindakan tersebut akan sangat berfaedah dalam keberhasilan pembuktian, keterangan terdakwa yang diberikan diharapkan akan valid karena yang bersangkutaan mengetahui semua peristiwa tindak pidana yang didakwakan. Dari penilaian demikian, tercipta istilah "saksi kunci" yang diartikan saksi yang amat penting. Saksi kunci inilah yang dalam praktik hukum kita disamaartikan dengan saksi mahkota. ${ }^{37}$

${ }^{37}$ Hendar Soetarna, Hukum Pembuktian..., 65. 
Dengan demikian dalam proses pembuktian tindak pidana perjudian di Pengadilan Negeri Bangkalan dengan mengajukan saksi mahkota dibenarkan karena beberapa alasan:

1. Kurangnya alat bukti.

2. Sebagai petunjuk hakim dalam memutus perkara tersebut.

3. Dibenarkan dalam Yurisprudensi Mahkamah Agung No. 1986K/Pid/1989 Tanggal 21 Maret 1990.

Tanpa adanya saksi mahkota, hakim tidak bisa memperkuat alat bukti lainnya yang ditujukan oleh penuntut umum, karena dikira saksi mahkotalah yang dapat dijadikan petunjuk hakim dalam memutus perkara perjudian tersebut. Dan alasan kekurangan alat bukti inilah yang menjadikan saksi mahkota tetap digunakan dalam proses peradilan sesuai dengan Yurisprudensi Mahkamah Agung No. 1986K/Pid/1989 Tanggal 21 Maret 1990 bahwa "jaksa penuntut umum boleh mengajukan teman terdakwa yang ikut serta dalam pidana sebagai saksi dengan syarat tidak masuk dalam berkas terdakwa pertama”.

\section{Penerapan Saksi Mahkota dalam Putusan Nomor 216/Pid.B/2012/PN.Bkl. Perspektif Fiqh Murâfa'ât}

Secara umum dalam hukum acara pidana Islam, pembuktian dibebankan kepada penggugat atau pihak yang merasa dirugikan, agar sesuai dengan tuntutan yang dibuat oleh pihak yang merasa dirugikan. Sesuai dengan hadis Nabi saw:

"Dan dari Baihaqi dengan sanad yang sahîh: bukti (diwajibkan)

atas pendakwah, dan sumpah diwajibkan atas yang ingkar"

Hadis di atas menunjukkan bahwa dalam Islam yang diwajibkan dalam melakukan pembuktian adalah pihak yang menuntut dan seorang yang dituntut. Penggugat diminta mengajukan bukti-bukti untuk memperkuat gugatannya dalam dua hal. Pertama, apabila tergugat menolak gugatannya seluruh atau sebagian, dan tidak dapat membawakan bukti perlawanannya atau dapat membawa bukti perlawanannya tetapi tidak dapat diterima. Kedua, apabila telah mengakui seluruh isi gugatan, tetapi penggugat menginginkan suatu putusan yang berakibat kepada pihak-pihak lain selain orang yang mengaku tersebut. ${ }^{38}$

\footnotetext{
${ }^{38}$ Basiq Djalil, Peradilan Islam, (Jakarta: Amzah, 2012), 39.
} 
Penjelasan di atas menunjukkan bahwa hukum acara pidana hampir sama dengan hukum acara pidana Islam. Hukum acara pidana mewajibkan penyidik untuk membuktikan sangkaannya dengan syarat adanya bukti yang memenuhi unsur-unsur pidananya. Hal ini diperkuat oleh aturan dalam Kitab Undang-Undang Hukum Acara Pidana bahwa tersangka tidak dibebani kewajiban pembuktian. ${ }^{39}$

Hukum acara pidana juga mengatur tentang hak tersangka atau terdakwa dalam mengajukan bukti berupa saksi yang dapat meringankan atau memberatkan bagi dirinya. Hak tersangka atau terdakwa dalam mengajukan saksi yang meringankan bagi dirinya merupakan kesempatan yang diberikan Undang-Undang dalam melakukan perlawanan. Ini terjadi dalam pembuktian kasus perjudian di Pengadilan Negeri Bangkalan, dimana hakim mengangkat saksi mahkota dalam acara pembuktian saksi. Katagori saksi mahkota ini merupakan saksi yang dapat meringankan dirinya sendiri, sedangkan dalam tedakwa pertama dia mengalami pemberatan hukuman karena saksi mahkota memberatkan baginya.

Secara global hukum Islam tidak menjelaskan mengenai saksi mahkota, tetapi dalam hukum Islam salah satu syarat saksi adalah adil. Maka dari itu keberadaan saksi mahkota sebagai alat bukti dalam penyelesaian perkara pidana dalam kasus ini merupakan kesaksian antara terdakwa terhadap terdakwa yang lain harus berada di bawah sumpah. Adapun terdakwa itu tidak dibebankan sumpah, sedangkan dalam perkara ini terdakwa yang posisinya juga sebagai saksi harus berada di bawah sumpah. Jika terdakwa bersumpah ini akan mengalami suatu keambiguan, bahwa dikarenakan terdakwa tidak dikenakan kewajiban untuk bersumpah maka terdakwa bebas untuk memberikan keterangannya di hadapan persidangan. Sebaliknya, dalam hal terdakwa diajukan sebagai saksi mahkota, tentunya terdakwa tidak dapat memberikan keterangan secara bebas karena terikat dengan kewajiban untuk bersumpah. Konsekuensi dari adanya pelanggaran terhadap sumpah tersebut maka terdakwa akan dikenakan atau diancam dengan dakwaan baru berupa tindak pidana kesaksian palsu.

Akan tetapi, keberadaan saksi mahkota sebagai alat bukti dalam perkara perjudian di Pengadilan Negeri Bangkalan ini diperbolehkan karena kurangnya alat bukti yang dibutuhkan dalam proses persidangan.

${ }^{39}$ Pasal 66 Kitab Undang-Undang Hukum Acara Pidana 
Saksi mahkota ini akan menjunjung nilai keadilan, dan mencari kemaslahatan dalam mencari keputusan yang adil.

Saksi mahkota yang sifatnya sebagai petunjuk bagi hakim dalam memutus perkara pidana tidak ditemukan dalam hukum acara pidana Islam, karena qorînah yang dimaksud dalam fiqh murâfa'ât adalah petunjuk yang jelas dan nyata.

Saksi mahkota ini dihukumi boleh karena alasan ḍarûrât, hakim kekurangan alat bukti dalam memutus perkara perjudian di Pengadilan Negeri Bangkalan ini, maka dari itu dikeluarkanlah saksi kunci untuk bisa memutus perkara tersebut. Konsep ḍarûrât dalam hukum Islam diperbolehkan, sesuai dengan dalil kaidah fiqhiyah yaitu: ${ }^{40}$

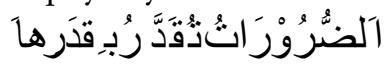

"Sesuatu yang diperbolehkan karena ḍrûrât, harus diperkirakan menurut batasan ukuran kebutuhan minimal".

Kaidah diatas sesungguhnya membatasi manusia dalam melakukan yang dilarang karena kondisi ḍarûrât. Seperti telah dijelaskan melakukan yang haram karena darûrât tidak boleh melampaui batas, tetapi hanya sekedarnya. Oleh sebab itu, jika kemudharatan atau keadaan yang memaksa tersebut sudah hilang, maka hukum kebolehan yang berdasarkan kemudharatan menjadi hilang juga, artinya perbuatan boleh kembali keasal semula, yaitu terlarang. ${ }^{41}$

Dari adanya kaidah tersebut, maka muncul kaidah sebagai berikut:

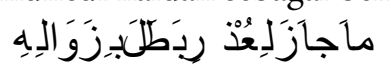

"Apa saja kebolehannya karena ada alasan kuat ('udhur), maka

hilangnya kebolehan itu disebabkan oleh hilangnya alasan".

Jadi saksi mahkota dalam putusan No.216/Pid.B/2012/PN.Bkl dihukumi sebagai hukum darûrât. Hukum asal saksi adalah boleh dan merupakan syarat dari pada pembuktian, tetapi saksi mahkota yang merupkan saksi yang masih dipertanyakan keberadaannya yang subjeknya adalah terdakwa, itu tidak diperbolehkan karena pembuktian hanya pada orang yang mengingkari tuduhan. Karena adanya beberapa indikasi yakni saksi mahkota ini sangat diperlukan untuk menunjang keadilan maka saksi mahkota diperbolehkan tetapi hanya dihukumi

${ }^{40}$ Djazuli, Kaidah-Kaidah Fiqih, Kaidah-Kaidah Hukum Islam dalam Menyelesaikan MasalahMasalah yang Praktis, (Jakarta: Pranada Media Grup, 2007), 73.

${ }^{41}$ Muhammad Mas'ud Zein, Sistematika Teori Hukum Islam (Qawâ'id-Fighiyyah), (Jawa Timur: AlSyarîfah Al-Khadîzah, 2006), 66. 
dadurat. Jika saksi mahkota ini tidak diperlukan maka hakim tidak boleh mengangkat saksi mahkota dalam proses pembuktian dengan alasan apapun.

Akan tetapi penggunaan saksi mahkota sebagai alat bukti, jika ada alat bukti lain, seperti saksi yang memadai, pengakuan / alat bukti yang tertulis dan sumpah, maka saksi mahkota ditinggalkan karena syarat keadilan tidak terpenuhi oleh saksi mahkota. Disebabkan karena saksi ini merupakan para terdakwa yang dijadikan saksi dalam artian orang yang tertuduh melakukan kemaksiatan. Sehingga terdapat syarat yang tidak dapat terpenuhi oleh saksi mahkota. Syarat tersebut adalah syarat adilnya saksi atau dalam hukum Islam diistilahkan dengan al-'adâlah. Dengan tidak terpenuhinya syarat adil ini menyebabkan kesaksiannya tidak diterima.

\section{Simpulan}

Konsep saksi mahkota adalah saksi yang berstatus sebagai terdakwa dalam hal perkara pidana yang sama, yang dilakukan pemisahan. Dalam putusan No.216/Pid.B/2012/PN.Bkl tentang perkara perjudian di Pengadilan Negeri Bangkalan, hakim mengangkat saksi mahkota sebagai saksi terhadap terdakwa pertama dengan alasan kurangnya alat bukti dalam memutus perkara tersebut. Adanya penggunaan saksi mahkota ini dibenarkan dalam Yurisprudensi Mahkamah Agung No. 1986K/Pid/1989 tanggal 21 Maret 1990 bahwa "jaksa penuntut umum boleh mengajukan teman terdakwa yang ikut serta dalam pidana sebagai saksi dengan syarat tidak masuk dalam berkas terdakwa pertama”. Tanpa adanya saksi mahkota, hakim tidak bisa memperkuat alat bukti lainnya yang ditujukan oleh penuntut umum, karena dikira saksi mahkotalah yang dapat dijadikan petunjuk hakim dalam memutus perkara perjudian tersebut. Dan alasan kekurangan alat bukti inilah yang menjadikan saksi mahkota tetap digunakan dalam proses peradilan

Dalam fiqh murâfa'ât keberadaan saksi mahkota sebagai alat bukti dalam perkara perjudian di Pengadilan Negeri Bangkalan ini diperbolehkan dengan hukum d̦arûrât yaitu "Sesuatu yang diperbolehkan karena darûrât, harus diperkirakan menurut batasan ukuran kebutuhan minimal". Saksi mahkota diangkat sebagai saksi karena keadaan ḍrûrât yaitu karena kurangnya alat bukti yang 
dibutuhkan dalam proses persidangan. Saksi mahkota ini akan menjunjung nilai keadilan, dan mencari kemaslahatan dalam mencari keputusan yang adil. Saksi mahkota yang sifatnya sebagai petunjuk bagi hakim dalam memutus perkara pidana tidak ditemukan dalam hukum acara pidana Islam, karena qarînah yang dimaksud dalam fiqh murâfa'ât adalah petunjuk yang jelas dan nyata.

\section{Daftar Rujukan}

Anshoruddin. Hukum Pembuktian Menurut Hukum Acara Islam dan Hukum Positif. Yogyakarta: Pustaka Pelajar, 2004.

Aziz Dahlan, Abdul. Ensiklopedi Hukum Islam. Jakarta: Icthtiar Baru Van Hoeve, 1996.

Depag RI. Al-Qur’an dan Terjemahannya. Jakarta: CV Atlas, 1998.

Djalil, Basiq. Peradilan Islam. Jakarta: Amzah, 2012.

Djazuli. Kaidah-Kaidah Fiqh, Kaidah-Kaidah Hukum Islam dalam Menyelesaikan Masalah-Masalah yang Praktis. Jakarta: Pranada Media Grup, 2007.

Hamzah, Andi. Hukum Acara Pidana Indonesia. Jakarta: Sinar Grafika, 2008.

Hendra, Jonizul. "Renungan Saksi Mahkota dalam Islam", dalam http://jonizulhendra.blogspot.com/2014/02/normal-0-false-falsefalse-en-us-x-none.html, diakses pada 12 Juni 2014

Jauziyah (al-), Ibnu Qayyim. Hukum Acara Peradilan Islam. Yogyakarta: Pustaka Pelajar, 2006.

Kansil. Pengantar Ilmu Hukum dan Tata Hukum Indonesia. Jakarta: Balai Pustaka, 1989.

Lubis, Sulaikhan. Hukum Acara perdata Peradilan Agama di Indonesia. Jakarta: Kencana Prenada Media Group, 2005.

Mas'ud Zein, Muhammad. Sistematika Teori Hukum Islam (Qawâ'idFiqhiyyah). Jawa Timur: Al-Syarîfah Al-Khadîzah, 2006.

Moeljatno. Hukum Acara Pidana. Yogyakarta: UGM, t.th.

Mulyadi, Lilik. Putusan Hakim dalam Hukum Acara Pidana: Teori, Praktik, Teknik Penyusunan dan Permasalahannya. Bandung: Citra Aditya Bakti, 2007. 
Saabiq, Sayyid. Fikih Sunnah 14, terj. Mahyuddun Syaf. Bandung: PT Alma'arif, 1978.

Soesilo, R. Teknik Berita Acara (Proses Verbal) Ilmu Bukti dan Laporan. Bogor: Politea, 1980.

Soetarna, Hendar. Hukum Pembuktian Dalam Acara Pidana. Bandung: PT Alumni, 2011.

Sutarto, Suryono. Hukum Acara Pidana Jilid I. Semarang: Badan Penerbit UNDIP, 1991.

Tim Permata Pers. KUHAP (Kitab Undang-Undang Hukum Acara Pidana) dan Penjelasannya. t.tp.: Gama Press, 2010.

Wibowo, Dwinanto Agung. "Peranan Saksi Mahkota Dalam Peradilan Pidana Di Indonesia”, dalam htttp//lontar.ui.ac.id/file? file $=$ digital $/ 20252706-T 28577$-peranan\%20saksi.pdf diakses pada Selasa, 18 Maret 2014, pukul 00:43 WIB 